\title{
Hepatitis A: an epidemiological survey in blood donors, France 2015 to 2017
}

Pierre Galliann ${ }^{1,2}$, Valérie Barlet³, Lina Mouna4, Sylvie Gross5, Sophie Lecam6, Céline Ricard7, Françoise Wind ${ }^{8}$, Elodie Pouchol5, Cécile Fabra ${ }^{1}$, Benoit Flan', Catherine Visse', Rachid Djoudi5, Elisabeth Couturier ${ }^{10}$, Henriette de Valk ${ }^{10}$, Pierre Tiberghien ${ }^{5,11}$, Anne-Marie Roque-Afonso ${ }^{4}$

1. Etablissement Français du Sang Provence Alpes Côte d’Azur et Corse, Marseille, France

2. Unité des Virus Emergents (UVE: Aix-Marseille Univ - IRD 190 - Inserm 1207 - IHU Méditerranée Infection), Marseille, France

3. Etablissement Français du Sang Auvergne Rhône Alpes, Beynost, France

4. AP-HP, Hôpital Paul'Brousse, Virologie, CNR des Virus des hépatites à transmission entérique, INSERM U1993, Villejuif, France

5. Etablissement Français du Sang, Saint Denis-La Plaine Stade de France, France

6. Etablissement Français du Sang Centre Pays de Loire, Nantes, France

7. Etablissement Français du Sang Haut de France, Lille, France

8. Etablissement Français du Sang Occitanie, Toulouse, France

9. LFB BIOMEDICAMENTS, Courtaboeuf, France

10. Santé Publique France, French national public health agency, Saint-Maurice, France

11. Université de Franche-Comté, Inserm, Etablissement Français du Sang, UMR 1098, Besançon, France

Correspondence: Pierre Gallian (pierre.gallian@efs.sante.fr)

Citation style for this article:

Gallian Pierre, Barlet Valérie, Mouna Lina, Gross Sylvie, Lecam Sophie, Ricard Céline, Wind Françoise, Pouchol Elodie, Fabra Cécile, Flan Benoit, Visse Catherine, Djoudi Rachid, Couturier Elisabeth, de Valk Henriette, Tiberghien Pierre, Roque-Afonso Anne-Marie. Hepatitis A: an epidemiological survey in blood donors, France 2015 to 2017. Euro Surveill. 2018;23(21):pii=1800237. https://doi.org/10.2807/1560-7917.ES.2018.23.21.1800237

Since mid-2016, hepatitis A virus (HAV) outbreaks, involving predominantly men who have sex with men (MSM), have affected countries in Europe and overseas. In France, HAV screening of blood donations in 2017 revealed a HAV-RNA prevalence cafivefold higher than during $2015^{-16}$ (4.42/106 vs $0.86 / 106$; $\mathrm{p}=0.0005)$. In 2017, despite a higher male-to-female ratio (5.5 vs 0.7 ) and the identification of MSMassociated outbreak strains, only one of 11 infected male donors self-reported being a MSM.

Since mid-2016, outbreaks involving mainly men who have sex with men (MSM) have been reported in European countries and overseas [1-6]. The outbreaks were associated with three genotype IA hepatitis A virus (HAV) strains: VDR_521_2016, RIVM_HAV16-090 and $V_{16}-25801$. In this study, we report epidemiological and clinical findings pertaining to HAV infected blood donors before and during the recent outbreak in France.

\section{Blood donation screening for hepatitis A virus}

In France, nucleic acid test (NAT) screening for HAV is not mandatory for blood donation but is a voluntary requirement since 2000 for plasma intended for the manufacture of plasma-derived medicinal products by LFB Biomédicaments, Courtaboeuf, France. Since 2015, HAV NAT screening is carried out, on behalf of LFB Biomédicaments, by the French transfusion public service (Etablissement Français du Sang: EFS). Although the screening requirements remain unchanged, EFS tests all blood donations for therapeutic use (pools of 48 samples until February 2017 and pools of 96 subsequently) using the duplex kit Procleix HAV/B19 assay on the Tigris System automation (Grifols Diagnostic Solutions, Inc., Emeryville, California (CA)/Hologic, Inc., San Diego, (A). This system has a $95 \%$ level of detection for HAV-RNA of ca $1 \mathrm{lU} / \mathrm{mL}$ in individual testing, and thus a $95 \%$ level of detection of ca $100 \mathrm{IU} / \mathrm{mL}$ in pool testing ( 96 samples). Candidates for donation with signs suggestive of infectious diseases and/or fever $38^{\circ} \mathrm{C}$ are deferred until 2 weeks after the end of symptoms. Since July 2016 , MSM permanent deferral has been reduced to one year, with the exception of apheresis quarantined plasma where identical deferral rules now apply to all donors [7].

\section{Findings in blood donations before and during the 2017 outbreak}

In mainland France, the number of reported laboratory-confirmed hepatitis A cases in the general population increased from 701 and 666 in 2015 and 2016 respectively to over 2,980 cases during the first 10 months of 2017 with a maximum in July 2017 [8]. In 2015 and 2016, a period without major hepatitis A outbreaks in France, five blood donors were found positive for HAV-RNA among 5.84 million tested-donations. The frequency of positive HAV-RNA donations was $0.86 / 10^{6}$ donations with a male to female (M/F) ratio of 0.7. Of interest, the HAV-RNA screening was able to detect the inactivated vaccine strain in two blood donors in the days (D) following vaccination ( $D+1$ and $D+5)$. These two cases were not included in our survey. 
Monthly number of laboratory-confirmed hepatitis A cases stratified by cases in the general population and hepatitis A virus-RNA positive blood donations, France, 2017 ( $\mathrm{n}=3,389)$

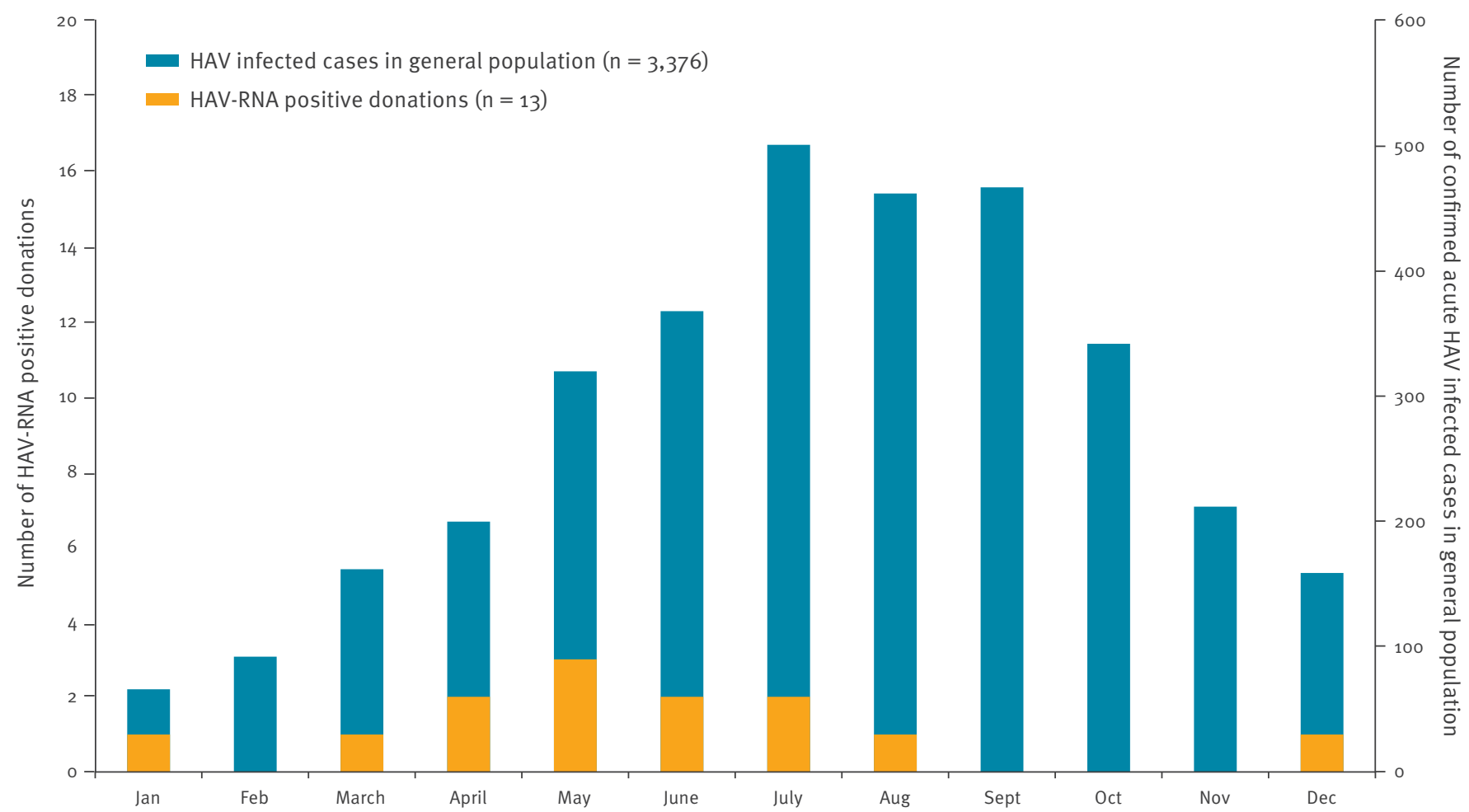

HAV: hepatitis A virus.

Data obtained through the national mandatory reporting system [8].

In contrast, a significant increase in the number of HAV-RNA-positive blood donors was observed in 2017 with 13 positive donations resulting in a frequency of $4.4 / 10^{6}$ donations, significantly higher than in the 2015-16 period $(p=0.0005)$. Between April and July, frequency peaked at $9.4 / 10^{6}$ donations, at a time when the number of cases in the general population was still increasing (Figure).

Blood donations found HAV-RNA-positive in 2017 involved two women and 11 men $(M / F$ ratio $=5.5)$. Genotype IA outbreak-associated strains were identified in 12 of 13 cases (VDR_521_2016: $n=5$; RIVMHAV16-090: $n=7$ ) and a genotype IIIA was identified in one case. Viral loads ranged from 1.2 to 8.59 log10 $\mathrm{IU} / \mathrm{mL}$.

None of the blood donors found HAV-RNA-positive throughout the whole study (2015-17) had symptoms at the time of donation. Sixteen donors subsequently reported clinical symptoms compatible with acute HAV infection. Among these, 11 had symptoms 2 to 12 days after donation. One donor reported symptoms at day 31 post-donation, while two had had symptoms 2 and 8 weeks before donation, respectively. Two donors failed to date the occurrence of clinical symptoms. In nine donors, systematic notification of the HAV-RNApositive blood donation resulted in the diagnosis of asymptomatic $(n=2)$ or pauci-symptomatic $(n=7)$, previously unsuspected HAV infections.

The epidemiological investigation of the HAV-RNApositive blood donors included questions about their job, the presence of HAV infected persons in their circle of family and friends, the presence of children < 3 years-old, travel history, and seafood consumption. Sexual risk factors were not systematically investigated. Among positive HAV-RNA blood donors, seafood consumption was the most frequently reported risk factor $(n=7)$. Other exposure risks were professional exposure $(n=3$; including a fruit and vegetable producer, a social worker and a wastewater treatment plant worker), contact with a person infected with HAV $(n=2)$, travel to a hepatitis A endemic area $(n=1)$ and MSM $(n=1)$; three individuals had two risk factors. In six cases including four men in 2017 , no risk factor was identified.

\section{Follow-up of positive blood products}

Among the 12 red blood cell concentrates (RBC) from HAV-RNA-positive donations, nine were destroyed, and three already transfused before detection. All platelet 
Blood donors' characteristics, virological data and follow up of HAV infected blood products, France, $2015-2017$ (n=18 HAV-RNA-positive donations)

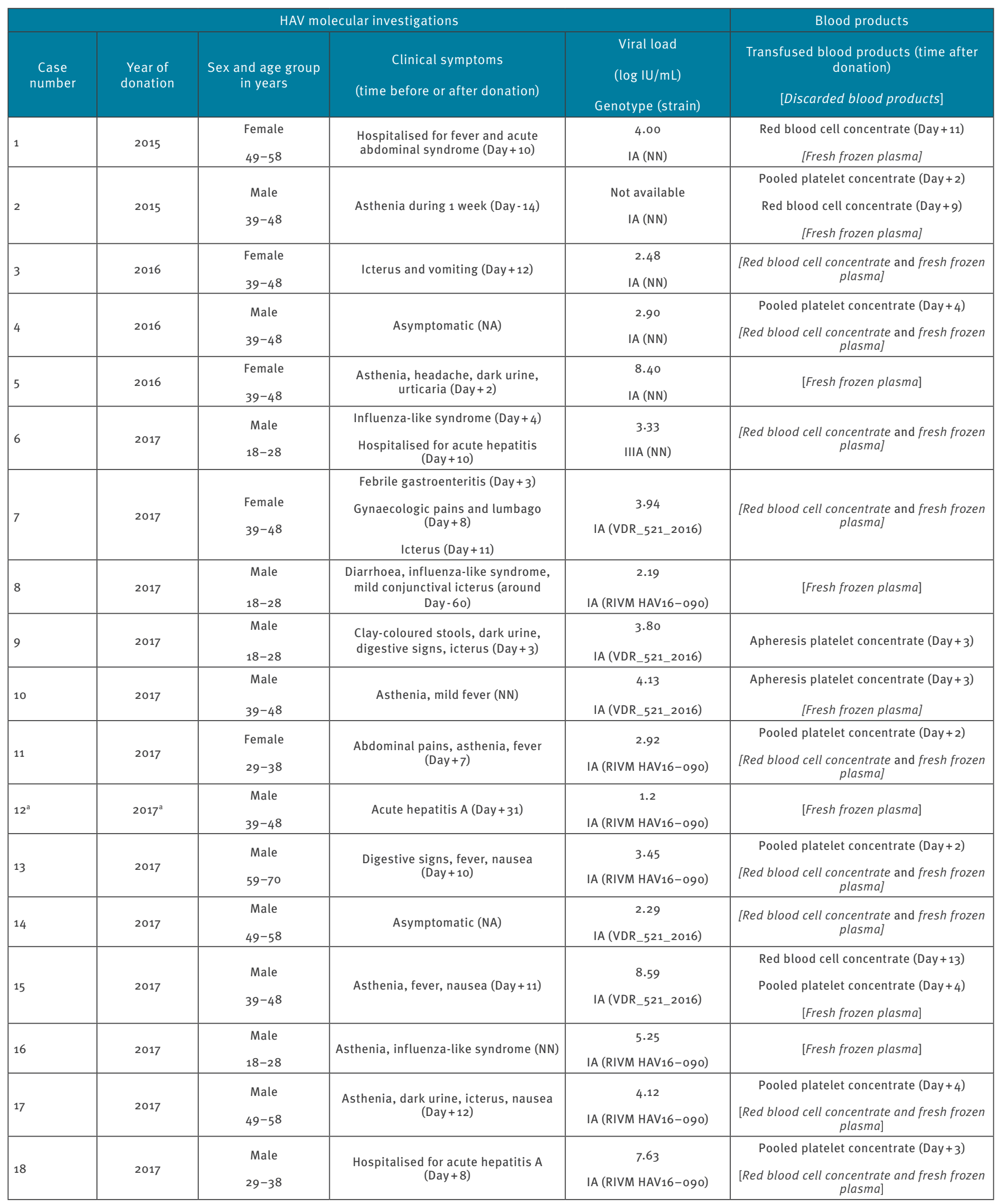

HAV: hepatitis A virus; NA: not applicable; NN: not known.

Viral strains were characterised as previously published [20]. Viral load in individual samples was assessed with the RealStar HAV RT-PCR Kit (Altona Diagnostics, Hamburg, Germany) with serial dilutions of the World Health Organization International Standard sample for HAV-RNA nucleic acid testing assays (NIBSC, Hertfordshire, United

Kingdom) as quantification curve. Lower quantification limit was estimated at $10 \mathrm{IU} / \mathrm{mL}$. Delay between donation date and date of identification of HAV-RNA positive donation varied but did not exceed 30 days. Upon HAV positivity detection in a pooled sample, Etablissement Français du Sang (EFS) procedure calls for a rapid identification of the var-infected donor.

${ }^{a}$ This donor did not initially test HAV-RNA positive in pool screening, but after this person reported clinical symptoms one month post-donation, repeat testing of the individual sample found it positive. Initial negative NAT screening (pool of 96) result may be explained by a viral $\operatorname{load}(1.2 \mathrm{log} 10 \mathrm{IU} / \mathrm{mL}$ ) under the $95 \%$ limit of detection (estimated for pool of 96 at around $2 \log 10 \mathrm{lU} / \mathrm{mL}$ ). 
concentrates (PC) (whole blood-derived pooled platelets $n=7$, apheresis platelets $n=2$ ) were transfused before availability of NAT results (2-16 days after donation). Lastly, all collected plasma were destroyed $(n=17)$. Haemovigilance enquiry of all 12 HAV-RNApositive blood transfusions ( $3 \mathrm{RBC}$ and $9 \mathrm{PC}$ ) revealed one case of transfusion-transmitted hepatitis A (TTHA) by the presence of HAV-RNA 7 days after transfusion in a recipient who tested RNA and IgM negative, but IgG positive with a low index ratio two days before transfusion. TTHA was confirmed by molecular comparison of involved viral strains in donor and recipient. As the survey of other recipients did not unfortunately allow full documentation of their serological and molecular status before and after transfusion, additional TTHA cases cannot be formally excluded.

\section{Discussion}

Hepatitis A acute infection is mainly asymptomatic in children under 6 years-old, and the proportion and the severity of symptomatic forms increase with age. After a ca 30-days incubation period, the infection is typically mild and self-limited, characterised in most cases by an 'influenza-like' syndrome, digestive disorders and jaundice. In most cases, infection resolves within a few weeks with no reported chronic forms. However, rare cases of fulminant hepatitis with liver failure, most often fatal, are observed in elderly patients [9].

HAV transmission occurs through a faecal-oral route either through direct contact with an infected individual or through the consumption of contaminated water or contaminated raw food such as seafood or soiled vegetables [10]. Outbreaks occur mainly in kindergartens, in communities with precarious living conditions, or among MSM. Among the latter, outbreaks associated with sexual practices such as oro-anal or digitoanal sex have been described since the 1970s [11].

In this study, the involved HAV strains as well as the increased $\mathrm{M} / \mathrm{F}$ ratio in 2017 suggest that sexual risk factors were under-reported and/or inadequately investigated. The recent hepatitis A virus outbreaks in Europe have involved predominantly MSM. However, during large-scale outbreaks, many individuals who do not belong to a specific risk group can get infected because HAV may spread to a larger population by direct contacts or by food handlers, especially since some infected individuals may have no symptoms. Moreover, by the end of 2017, the number of women infected by one of the outbreak-associated HAV strains had increased suggesting a spillover to non-MSM individuals [12]. In our survey, two women (cases 7 and 11) were infected by such strains.

All HAV-RNA-positive blood donors in this study were asymptomatic at the time of donation. The delay of 2 to 12 days found between donation and symptom onset in 11 of $16 \mathrm{HAV}$-RNA-positive donors who subsequently reported symptoms, is in accordance with previous TTHA published data indicating that infected blood products were collected between 6 and 18 days before the onset of clinical symptoms [13].

One case of TTHA was detected. TTHA is extremely rare [13-18]. This is likely due to the absence of chronic carriage, the high frequency of symptomatic forms in adults, and anti-HAV immunity in transfusion recipients as well as in blood donors. However, it should be noted that HAV seroprevalence in industrialised countries is currently decreasing. In 2008-10, HAV seroprevalence in France was $22 \%$ and $46 \%$ for the age groups of 20-29 years and 40-49 years respectively [19].

The risk of HAV transmission by infected blood products could be mitigated by improving donor education to immediately notify the blood bank of any symptoms occurring after blood donation as well as by blood donation HAV NAT, ideally performed shortly after donation to allow all blood products to be discarded before use. In addition to donor vaccination, these measures may also contribute to limit secondary transmission within the hospital setting or intra-familial exposure.

\section{Conclusions}

To our knowledge, this large-scale study is the first to estimate the risk of collecting HAV-infected blood donations before and during a hepatitis A outbreak. During the 2017 HAV outbreak in France, the risk of collecting asymptomatic blood donors increased while remaining a rare event. Nevertheless, at least one TTHA occurrence was observed. Lastly, our results highlight the potential for blood donor screening to alert and/or inform of an epidemic situation.

\section{Erratum}

In some cells of the Table, the year was incorrectly displayed. This was corrected on 25 May 2018.

\section{Conflict of interest}

None declared.

\section{Authors' contributions}

Valérie Barlet, Sophie Lecam, Céline Ricard, Françoise Wind and Cecile Fabra performed NAT screening in the French transfusion public service laboratories. Elodie Pouchol collected data from haemovigilance. Elisabeth Couturier collected data from general population. Henriette de Valk, Sylvie Gross, Rachid Djoudi, Benoit Flan and Catherine Visse analysed the data. Lina Mouna, Anne-Marie Roque-Afonso supervised viral loads estimation and molecular typing. Pierre Gallian, Anne-Marie Roque-Afonso and Pierre Tiberghien drafted the manuscript. All authors participated in review of the manuscript.

\section{References}

1. European Centre for Disease Prevention and Control (ECDC). Hepatitis A outbreak in the EU/EEA mostly affecting men who have sex with men, third update, 28 June 2017 . Stockholm: 
ECDC; 2017. [Accessed 12 March 2018]. Available from: https:// ecdc.europa.eu/en/publications-data/rapid-risk-assessmenthepatitis-outbreak-eueea-mostly-affecting-men-who-have-sex

2. World Health Organization (WHO). Hepatitis A outbreaks mostly affecting men who have sex with men - European Region and the Americas. Geneva: WHO; 7 Jun 2017. [Accessed 12 March 2018]. Available from: http://www.who.int/csr/ don/o7-june-2017-hepatitis-a/en/

3. Werber D, Michaelis K, Hausner M, Sissolak D, Wenzel J, Bitzegeio J, et al. Ongoing outbreaks of hepatitis $A$ among men who have sex with men (MSM), Berlin, November 2016 to January 2017 - linked to other German cities and European countries. Euro Surveill. 2017;22(5):30457. https://doi. org/10.2807/1560-7917.ES.2017.22.5.30457 PMID: 28183391

4. Beebeejaun K, Degala S, Balogun K, Simms I, Woodhall SC, Heinsbroek E, et al. Outbreak of hepatitis A associated with men who have sex with men (MSM), England, July 2016 to January 2017. Euro Surveill. 2017;22(5):30454. https://doi. org/10.2807/1560-7917.ES.2017.22.5.30454 PMID: 28183392

5. Freidl GS, Sonder GJ, Bovée LP, Friesema IH, van Rijckevorsel GG, Ruijs WL, et al. Hepatitis A outbreak among men who have sex with men (MSM) predominantly linked with the EuroPride, the Netherlands, July 2016 to February 2017. Euro Surveill. 2017;22(8):30468. https://doi.org/10.2807/1560-7917. ES.2017.22.8.30468 PMID: 28251892

6. Rivas V, Barrera A, Pino K, Núñez R, Caceres CJ, Lopez-Lastra $M$, et al. Hepatitis A outbreak since November 2016 affecting men who have sex with men (MSM) in Chile connected to the current outbreak in MSM in Europe, situation up to October 2017. Euro Surveill. 2018;23(9):18-0006o. https:// doi.org/10.2807/1560-7917.ES.2018.23.9.18-00060 PMID: 29510780

7. Tiberghien P, Pillonel J, Toujas F, Vallet B. Changes in France's Deferral of Blood Donation by Men Who Have Sex with Men. N Engl J Med. 2017;376(15):1485-6. https://doi.org/10.1056/ NEJMC1700740 PMID: 28402774

8. Sante publique France. Epidémie d'hépatite A en France et en Europe - Point de situation au 13 novembre 2017. [Hepatitis A outbreak in France and in Europe - Situation as at 13 november 2017]. Paris: Sante publique France. [Accessed 12 March 2018]. French. Available from: http://invs.santepubliquefrance. $\mathrm{fr} /$ Dossiers-thematiques/Maladies-infectieuses/ Hepatites-virales/Hepatite-A/Points-d-actualite/Epidemied-hepatite-A-en-France-et-en-Europe-Point-de-situation-au-13novembre-2017

9. American Association of Blood Banks. Hepatitis A. July 2013: update to TRANSFUSION 2009;49(Suppl):87-9S. [Accessed 12 March 2018].

10. Nygård K, Andersson Y, Lindkvist P, Ancker C, Asteberg I, Dannetun E, et al. Imported rocket salad partly responsible for increased incidence of hepatitis A cases in Sweden, 20002001. Euro Surveill. 2001;6(10):151-3. https://doi.org/10.2807/ esm.06.10.00380-en PMID: 11891384

11. Corey L, Holmes KK. Sexual transmission of hepatitis $A$ in homosexual men: incidence and mechanism. N Engl J Med. 1980;302(8):435-8. https://doi.org/10.1056/ NEJM198002213020804 PMID: 6243391

12. European Centre for Disease Prevention and Control (ECDC). Epidemiological update: hepatitis A outbreak in the EU/EEA mostly affecting men who have sex with men. 22 dec 2017. Stockholm: ECDC; 2017. [Accessed 12 March 2018]. Available from: https://ecdc.europa.eu/en/news-events/epidemiologicalupdate-hepatitis-outbreak-eueea-mostly-affecting-men-whohave-sex-men-o

13. Gowland P, Fontana S, Niederhauser C, Taleghani BM. Molecular and serologic tracing of a transfusion-transmitted hepatitis A virus. Transfusion. 2004;44(11):1555-61. https:// doi.org/10.1111/j.1537-2995.2004.04071.x PMID: 15504159

14. Hollinger FB, Khan NC, Oefinger PE, Yawn DH, Schmulen $A C$, Dreesman GR, et al. Posttransfusion hepatitis type A. JAMA. 1983;250(17):2313-7. https://doi.org/10.1001/ jama.1983.03340170039025 PMID: 6313973

15. Diwan AH, Stubbs JR, Carnahan GE. Transmission of hepatitis A via WBC-reduced RBCs and FFP from a single donation. Transfusion. 2003;43(4):536-40. https://doi.org/10.1046/ j.1537-2995.2003.00342.x PMID: 12662288

16. Garraud O, Conductier R, Odent-Malaure H, Carrières J, Chopart $P$, Brenas F, et al. Silent transfusion-transmitted hepatitis A virus infection in an infant. Transfusion. 2004;44(7):1121 2. https://doi.org/10.1111/j.1537-2995.2004.00403.x PMID: 15225259

17. Hughes JA, Fontaine MJ, Gonzalez CL, Layon AG, Goodnough LT, Galel SA. Case report of a transfusion-associated hepatitis A infection. Transfusion. 2014;54(9):2202-6. https://doi. org/10.1111/trf.12648 PMID: 24689888
18. da Silva SG, Leon LA, Alves G, Brito SM, Sandes VS, Lima MM, et al. A Rare Case of Transfusion Transmission of Hepatitis A Virus to Two Patients with Haematological Disease. Transfus Med Hemother. 2016;43(2):137-41. https://doi. org/10.1159/000441910 PMID: 27226795

19. Lepoutre A, Antona D, Fonteneau L, Halftermeyer-Zhou F, Baudon C, Dorléans F, et al. Seroprevalence of vaccine preventable diseases and of five other infectious diseases in France. Results of two national surveys, 2008-2010. Bull Epidemiol Hebd (Paris). 2013; (41-42):526-34.

20. Desbois D, Couturier E, Mackiewicz V, Graube A, Letort MJ, Dussaix $\mathrm{E}$, et al. Epidemiology and genetic characterization of hepatitis A virus genotype IIA. J Clin Microbiol. 2010;48(9):3306-15. https://doi.org/10.1128/JCM.00667-10 PMID: 20592136

\section{License and copyright}

This is an open-access article distributed under the terms of the Creative Commons Attribution (CC BY 4.0) Licence. You may share and adapt the material, but must give appropriate credit to the source, provide a link to the licence, and indicate if changes were made.

This article is copyright of the authors, 2018. 